\title{
Losses through gases and effluent and nutritional value of Brachiaria decumbens with addition of soybean hulls
}

\author{
Carlos Clayton Oliveira Dantas ${ }^{1}$, Anderson de Moura Zanine ${ }^{2}$, Alexandre Lima de Souza ${ }^{2}$, \\ Luciano da Silva Cabral ${ }^{3}$, Fagton de Mattos Negrão', Edson Mauro Santos ${ }^{4}$, Daniele de Jesus \\ Ferreira $^{5}$
}

\footnotetext{
1 Programa de Pós-graduação em Ciência Animal, Universidade Federal de Mato Grosso, Cuiabá - MT, Brasil.

2 Departamento de Zootecnia, Universidade Federal de Mato Grosso, Rondonópolis - MT, Brasil.

${ }^{3}$ Departamento de Zootecnia e Extensão Rural, Universidade Federal de Mato Grosso, Cuiabá - MT, Brasil.

${ }^{4}$ Departamento de Zootecnia, Universidade Federal da Paraíba, Areia - PB, Brasil.

${ }^{5}$ Programa de Pós-graduação em Zootecnia, Universidade Federal de Viçosa, Viçosa - MG, Brasil.
}

\begin{abstract}
The objective of this experiment was to evaluate the losses of nutrient through gases and effluents, the nutrient recovery, fermentation parameters and the chemical parameters of silages of Brachiaria decumbens with the addition of soybean hulls, testing five levels of inclusion: 0, 10, 20, 30 and 40\% (as is), with five replications per treatment. After the standardization cut of the forage, performed at $5 \mathrm{~cm}$ from the soil level, the soil was fertilized with nitrogen and potassium in the form of ammonium sulfate and potassium chloride, respectively, at $60 \mathrm{~kg} / \mathrm{ha}$. After 60 days, the grass was cut at $10 \mathrm{~cm}$ from the soil and ensiled. Experimental silos with capacity of 10 liters with Bunsen valve were used. Silos had $3 \mathrm{~kg}$ of sand conditioned at the bottom for retention of the effluents. The results show that the contents of dry matter, crude protein, acid detergent insoluble fiber and total digestible nutrients presented positive linear behavior with the inclusion of soybean hulls. In the grass silages with addition of soybean hulls, there was greater recovery of dry matter in relation to the control silage, which is a reflection of the negative linear behavior for the values of losses of gases and effluent. There was quadratic behavior in the $\mathrm{pH}$ values and negative linear behavior for the ammonia $\mathrm{N}$ values and buffering capacity with the inclusion of the additive in the grass silage. Inclusion of soybean hulls is sufficient to improve the fermentation pattern and minimize the losses through gases and effluents, contributing to the nutrient recovery, in addition to promoting overall improvement of the nutritional value of Brachiaria grass silages.
\end{abstract}

Key Words: byproduct, conservation, ensilage, tropical grass

\section{Introduction}

Ensilage is a conservation process intended for the preservation of the forage in its moist form with high nutritional value, aimed at the minimum losses. However, during the ensilage processes, there are losses, because plants ensiled with elevated moisture produce a great amount of effluents, which is a very harmful process, since they carry highly digestible nutrients (sugars, organic acids, among others), diminishing the nutritional value of the silage.

There are studies in Brazil whose objective is to reduce the losses of nutrients through the generation of effluents and gases in the production of grass silage. The results from these studies revealed that as a way to reduce the losses,

Received July 23, 2012 and accepted February 18, 2014.

Corresponding author: claytonagm@zipmail.com.br

http://dx.doi.org/10.1590/S1516-35982014000500001

Copyright @ 2014 Sociedade Brasileira de Zootecnia. This is an Open Access article distributed under the terms of the Creative Commons Attribution Non-Commercial License, which permits unrestricted non-commercial use, distribution, and reproduction in any medium, provided the original work is properly cited. hygroscopic additives can be applied (Zanine et al., 2006ab; Zanine et al., 2010; Monteiro et al., 2011).

In Brazil, there are additives which present potential to be included in the process of grass silage production. However, the ingredient must present a high content of dry matter, high water holding capacity (hygroscopic), good acceptability, in addition to supplying carbohydrates to the microorganisms.

In this context, an additive that presents good characteristics and potential to be included in the production of grass silage is soybean hulls, with dry matter, crude protein, neutral detergent fiber and acid detergent fiber contents of $90,11.40,61.80$ and 46.25 , respectively (Lima, 2009). Due to this potential, Monteiro et al. (2011) evaluated the inclusion of four levels of soybean hulls in the ensilage of elephant grass, but did not obtain definitive conclusions as for the most appropriate level of inclusion.

Therefore, the objective of this experiment was to quantify the losses through gases and effluents and the fermentation pattern and the nutritional value of Brachiaria decumbens silages with addition of ground soybean hulls. 


\section{Material and Methods}

The climate, according to the Koppën classification, is tropical, characterized by two well-defined seasons: dry (from April to September) and rainy (from October to March).

The 0-20 centimeter deep soil layer presents the following chemical and physical characteristics: $\mathrm{pH}$ in $\mathrm{CaCl}_{2}=4.9 ; \mathrm{P}=1.7 \mathrm{mg} / \mathrm{dm}^{3} ; \mathrm{K}=29 \mathrm{mg} / \mathrm{dm}^{3} ; \mathrm{Ca}^{2+}=1 \mathrm{cmol} / \mathrm{dm}^{3}$; $\mathrm{Mg}^{2+}=1 \mathrm{cmol} / \mathrm{dm}^{3} ; \mathrm{H}+\mathrm{Al}^{3+}=2.9 \mathrm{cmol}_{\mathrm{c}} / \mathrm{dm}^{3} ; \mathrm{Al}^{3+}=0.1$ $\mathrm{cmol}_{\mathrm{c}} / \mathrm{dm}^{3}$; organic matter $=13.5 \mathrm{~g} / \mathrm{kg}$; sum of bases $=$ $2.1 \mathrm{cmol} / \mathrm{dm}^{3}$; cation-exchange capacity $=4.5 \mathrm{cmol} / \mathrm{dm}^{3}$; base saturation $=46 \%$; clay $=400 \mathrm{~g} / \mathrm{kg}$; silt $=100 \mathrm{~g} / \mathrm{kg}$; and total sand $=500 \mathrm{~g} / \mathrm{kg}$.

The forage species researched was Brachiaria decumbens, using a previously implanted brachiaria grass paddock of approximately 0.5 ha. A standardization cut was performed with this area with a mower coupled to a tractor $5 \mathrm{~cm}$ above the soil level. On the same day, the soil was fertilized with nitrogen and potassium in the form of ammonium sulfate and potassium chloride, respectively, at $60 \mathrm{~kg} / \mathrm{ha}$. Thus, the forage was cut at $10 \mathrm{~cm}$ from the soil for the ensilage process.

The experimental design was completely randomized, with five treatments and five replications: $100 \%$ brachiaria grass; $90 \%$ brachiaria grass $+10 \%$ ground soybean hulls; $80 \%$ brachiaria grass $+20 \%$ ground soybean hulls; $70 \%$ brachiaria grass $+30 \%$ ground soybean hulls; and $60 \%$ brachiaria grass $+40 \%$ ground soybean hulls (as is), composing the silages.

For the storage of the chopped green mass, experimental silos of capacity of approximately 10 liters were used. Silos were sealed and equipped with Bunsen valve on their lids to enable to the leak of the gases from fermentation. Three kilograms of sand were placed at the bottom of each experimental silo so that the amount of effluents produced could be measured.

Samples of the material before ensilage (approximately $500 \mathrm{~g})$ were collected, pre-dried in forced-ventilation oven at $65{ }^{\circ} \mathrm{C}$ for 72 hours and ground in Wiley mill for subsequent determination of dry matter (DM), crude protein $(\mathrm{CP})$, neutral detergent fiber (NDF), acid detergent fiber (ADF), soluble carbohydrates (SC), neutral detergent fiber corrected for ash and protein (NDFap) and buffering capacity (Table 1).

Silos were opened 40 days after ensilage. In the collection of samples, the $5 \mathrm{~cm}$ of the upper and lower parts of the silos were discarded; the first part of the silage (approximately $500 \mathrm{~g}$ ) was collected at the moment of opening, and conditioned in plastic bags and frozen for analysis of the ammonia nitrogen $\left(\mathrm{N}-\mathrm{NH}_{3}\right)$, according to the method described by Tosi (1973), and analysis of the buffering capacity, by the method of Playne and McDonald (1966).

The other part of the silage, approximately $500 \mathrm{~g}$ of sample, was inserted in plastic bags and pre-dried in forcedventilation oven at a temperature of $65^{\circ} \mathrm{C}$ for 72 hours. The pre-dried samples were weighed and ground with a Wiley mill with $1 \mathrm{~mm}$ mesh sieve, and stored in polyethylene containers for analyses of the contents of DM, CP, NDFap, $\mathrm{ADF}$ and ether extract (EE), according to methodologies of Silva and Queiroz (2002).

The values of total digestible nutrients (TDN) were estimated according to Van Soest (1994), by the equation:

$$
\operatorname{TDN}(\%)=\operatorname{Deg}+(1.25 * \mathrm{EE})-\mathrm{MM} \text {, }
$$

in which: Deg $=$ Degradability; $1.25=$ correction factor; $\mathrm{EE}=$ ether extract; and $\mathrm{MM}=$ mineral matter.

In the analyses of NDF, the samples were treated with thermo-stable $\alpha$-amylase because of the possibility of difficulty in filtering, without the use of sodium sulfite, according to Mertens (2002) and corrected for the contents of protein and ash according to descriptions of Licictra et al. (1996) and Mertens (2002), respectively.

The soluble carbohydrates were assessed according to the method reported by Bailey (1967). The principle of this method consists of extracting the carbohydrates with $80 \%$ alcohol solution in the reaction with acid solution prepared with anthrone and the reading is performed in a spectrophotometer using glucose solution to prepare the standard curve.

Table 1 - Mean values of nutrients of Brachiaria decumbens according to the levels of inclusion of soybean hulls and in the soybean hulls before ensilage

\begin{tabular}{|c|c|c|c|c|c|c|}
\hline \multirow{2}{*}{ Variables } & \multicolumn{5}{|c|}{ Levels of soybean hulls (\%) } & \multirow{2}{*}{ Soybean hulls $(\%)$} \\
\hline & 0 & 10 & 20 & 30 & 40 & \\
\hline Dry matter $^{1}$ & 26.73 & 44.01 & 50.23 & 55.66 & 59.22 & 90 \\
\hline Crude protein ${ }^{2}$ & 6.26 & 7.56 & 9.35 & 10.23 & 11.32 & 14 \\
\hline Soluble carbohydrates ${ }^{2}$ & 7.12 & 8.29 & 8.38 & 8.37 & 8.40 & 7.0 \\
\hline Acid detergent fiber ${ }^{2}$ & 55.41 & 50.22 & 55.72 & 56.36 & 56.98 & 53 \\
\hline Neutral detergent fiber corrected for ash and protein ${ }^{2}$ & 26.35 & 25.23 & 28.99 & 33.45 & 38.99 & 70 \\
\hline Buffering capacity (eq.mg HCl/100 g DM) & 16.22 & 15.03 & 13.69 & 13.28 & 11.94 & 9.3 \\
\hline
\end{tabular}


For the analysis of $\mathrm{pH}$, sub-samples of approximately $25 \mathrm{~g}$ were collected; $100 \mathrm{~mL}$ of distilled water were added to these sub-samples, which were left to rest for 2 hours. After this period, the $\mathrm{pH}$ was read with the aid of a potentiometer, according to the methodologies described by Silva and Queiroz (2002).

For organic acid analyses, $10 \mathrm{~mL}$ samples were diluted in water, acidified with $50 \% \mathrm{H} 2 \mathrm{SO} 4$ and filtered through Whatman filter paper (Kung Jr. and Ranjit, 2001) and $1 \mathrm{~mL}$ $20 \%$ metafosforic acid and $0.2 \mathrm{~mL} 0.1 \%$ phenic acid were added to $2 \mathrm{~mL}$ of the filtrate which was centrifuged later. The analyses of organic acids (lactic, acetic, propionic and butyric acids) were analyzed by high resolution liquid chromatography.

Losses through gases were based on the difference in the dry forage mass weight according to the equation below:

$$
\mathrm{G}(\% \mathrm{DM})=[(\mathrm{Wfsc}-\mathrm{Wfso}) /(\mathrm{GMef} \times \mathrm{DMef})] \times 1000,
$$

in which $\mathrm{G}(\% \mathrm{DM})=$ losses through gases; $\mathrm{Wfsc}=$ weight of the full silo $(\mathrm{kg})$ at silo closing; Wfso = weight of the full silo $(\mathrm{kg})$ at silo opening; GMef $=$ green mass $(\mathrm{kg})$ of ensiled forage; DMef = dry matter $(\mathrm{kg})$ of ensiled forage.

The losses through effluents were calculated through the equation below, based on the difference in sand weight and related to the fresh forage mass at closing.

$$
\mathrm{E}[(\mathrm{kg} / \mathrm{t} \mathrm{GM})=(\mathrm{Wessc}-\mathrm{Ts})]-(\mathrm{Wss}-\mathrm{Ts}) / \mathrm{GMfs}] \times 100,
$$

in which $\mathrm{E}[(\mathrm{kg} / \mathrm{t} \mathrm{GM})=$ losses through effluents; Wessc = weight of the empty silo with sand $(\mathrm{kg})$ at silo closing; Ts = tare of the silo; Wss = weight of the silo with sand $(\mathrm{kg})$ before insertion of the forage for the making of silage; GMfs = green mass of the forage $(\mathrm{kg})$ utilized in the making of the silage.

To determine the dry matter recovery, the following equation was utilized:

$$
\operatorname{DMR}(\%)=[(\text { GMfo } \times \text { DMfo }) /(\mathrm{DMs} \times \mathrm{DMsi})] \times 100,
$$
in which $\operatorname{DMR}(\%)=$ dry matter recovery as percentage; $\mathrm{GMfo}=$ green mass of the forage $(\mathrm{kg})$ at the time of ensilage;
DMfo $=$ dry matter of forage $(\%)$ at the time of ensilage; $\mathrm{DMs}=$ dry matter of the silage $(\mathrm{kg})$ at silo opening; DMsi $=$ dry matter of the silage $(\%)$ at silo opening.

The obtained data on the fermentation pattern, losses through gases and effluent, dry matter recovery and nutritional value of the silage of Brachiaria decumbens were analyzed statistically through analysis of variance ( $t$ test) and, in the cases of significance, regression analysis was conducted, by testing first- and second-degree polynomial models at 5\% significance level, utilizing the software Sistema para Análises Estatísticas e Genéticas (SAEG, version 8.1).

\section{Results and Discussion}

Quadratic effect $(\mathrm{P}<0.05)$ of the levels of soybean hulls was observed on the $\mathrm{pH}$ of the silages, with minimum point at the level of inclusion of $30.56 \%$ of soybean hulls, demonstrating once again that the intermediate levels are also interesting at the point of the $\mathrm{pH}$ value (Table 2). Zanine et al. (2010), assessing the effect of levels of dried cassava chips as additives for grass silages, reported that the minimum point occurred at the exact level of $20.75 \%$ for the $\mathrm{pH}$ value.

The $\mathrm{pH}$ value of the control silage of the present study could be considered precisely as a constraining factor to microbial growth. Based on the values considered ideal, described by McDonald et al. (1991), which vary from 3.8 to 4.2 , we can infer that the control silage and the treatment with addition of $10 \%$ soybean hulls had $\mathrm{pH}$ values above recommended, unlike the silages with over $20 \%$ inclusion of soybean hulls.

The buffering power and the ammonia nitrogen presented negative behavior $(\mathrm{P}<0.05)$, with an estimated decrease of 0.05 and $0.11 \%$ for each $1 \%$ soybean hulls added to the silage, respectively (Table 2). The silages studied differed significantly $(\mathrm{P}<0.05)$ as for the buffering power, probably because of the lower buffering capacity of the soybean hulls.

\begin{tabular}{|c|c|c|c|c|c|c|c|c|}
\hline \multirow{2}{*}{ Variables } & \multicolumn{5}{|c|}{ Levels of soybean hulls (\%) } & \multirow{2}{*}{ Regression equation* } & \multirow{2}{*}{$\mathrm{CV} \%$} & \multirow{2}{*}{$\mathrm{R}^{2}$} \\
\hline & 0 & 10 & 20 & 30 & 40 & & & \\
\hline $\mathrm{pH}$ & 4.90 & 4.49 & 4.23 & 4.13 & 4.18 & $\mathrm{Y}=4.9003-0.0489 \mathrm{X}+0.0008 \mathrm{X}^{2}$ & 1.15 & 98.75 \\
\hline BP (EQ-HCL) & 21.07 & 20.10 & 19.34 & 19.01 & 19.00 & $\mathrm{Y}=21.271-0.052 \mathrm{X}$ & 5.51 & 87.29 \\
\hline $\mathrm{N}-\mathrm{NH}_{3}(\% \mathrm{TN})$ & 14.28 & 14.13 & 12.50 & 12.19 & 9.55 & $\mathrm{Y}=15.09-0.116 \mathrm{X}$ & 3.86 & 43.00 \\
\hline LA (\% DM) & 3.18 & 4.82 & 4.35 & 3.89 & 3.55 & $Y=3.4317-0.111 \mathrm{X}+0.0028 \mathrm{X}^{2}$ & 9.79 & 78.01 \\
\hline $\mathrm{AA}(\% \mathrm{DM})$ & 1.539 & 1.223 & 0.997 & 0.971 & 0.901 & $Y=1.432-0.0153 \mathrm{X}$ & 8.65 & 81.21 \\
\hline $\mathrm{AB}(\% \mathrm{DM})$ & 0.098 & 0.079 & 0.072 & 0.081 & 0.083 & $Y=0.0965-0.191 X+0.005 X^{2}$ & 9.45 & 77.28 \\
\hline $\mathrm{PA}(\% \mathrm{DM})$ & 0.059 & 0.047 & 0.043 & 0.049 & 0.050 & $Y=0.0579-0.120 \mathrm{X}+0.005 \mathrm{X}^{2}$ & 10.45 & 75.89 \\
\hline
\end{tabular}

Table 2 - pH values, buffering power (BP), ammonia nitrogen (N-NH$)$, lactic acid (LA), acetic acid (AA), butyric acid (BA), propionic acid (PA) and their respective equations in the concentrations of soybean hulls in the silage of Brachiaria decumbens 
However, Monteiro et al. (2011) reported in their study that the buffering power of the silage of elephant grass forage, with and without the addition of soybean hulls, was not elevated, so it was not a major problem to the production of good-quality elephant grass silage. This conclusion can also be described in the present study, given that with $20 \%$ of inclusion of soybean hulls, the buffering power was estimated at 20.22 ethoxyquin hydrochloride (EQ-HCL); with $40 \%$ of inclusion, it was estimated at $19.18 \mathrm{EQ}-\mathrm{HCL}$; and the control silage presented 21.27 EQ-HCL.

The reduction in the $\mathrm{N}-\mathrm{NH}_{3}$ values probably stemmed from the inhibition of proteolytic microorganisms. According to McGechan (1989), greater $\mathrm{N}^{-\mathrm{NH}_{3}}$ values indicate higher intensity of proteolysis, and this is mainly due to the fermentation of the amino acid redox by the proteolytic clostridia. Therefore, Ribeiro et al. (2008) consider that $\mathrm{N}^{-\mathrm{NH}_{3}}$ is a product of the undesirable fermentation by Clostridium and, in well-conserved silages, the $\mathrm{N}^{-\mathrm{NH}_{3}}$ levels should not exceed $10 \%$ total N. Based on these values, it is clear that the Brachiaria decumbens silages enriched with soybean hulls presented desirable fermentations. Monteiro et al. (2011) did not observe alterations in the $\mathrm{N}^{-\mathrm{NH}_{3}}$ content of silages enriched with up to $15 \%$ of soybean hulls.

Quadratic behavior was observed for the values of lactic, butyric and propionic acids $(\mathrm{P}<0.05)$ with the addition of soybean hulls. There was a linear decrease in acetic acid with the addition of soybean hulls $(\mathrm{P}<0.05)$ (Table 2$)$. The reduction in the $\mathrm{pH}$ of the medium may have inhibited the development of enterobacteria and clostridia bacteria that produce these acids, reducing their concentration in the silage. Pires et al. (2009) observed values of 0.61 and $0.10 \%$ of dry matter for acetic and butyric acids, respectively, with the addition of $15 \%$ of cassava to the elephant grass silage with 80 days of regrowth.

The obtained results suggest that the use of soybean hulls as an additive in brachiaria grass silage should be made at intermediate levels, because this additive has high concentrations of dry matter, which favors lactic fermentation because of the inhibiting action on enterobacteria and clostridium bacteria development, resulting in lower values of butyric acid and propionic acid and greater values of lactic acid, which resulted in silage with a better fermentation profile.

At every $1 \%$ of soybean hulls included, the dry matter $(\mathrm{DM})$ content of the grass silage increased linearly $(\mathrm{P}<0.05)$ by 0.81 percentage units (Table 3 ). Such a fact can be attributed, among others, to the high content of dry matter of the soybean hulls $(90 \%)$ (Table 1), which promoted the decrease in the moisture of the grass by its high hygroscopic power.

The Brachiaria grass silage presents a low content of dry matter (Table 3), which is a characteristic of tropical climate grasses, which limit the obtainment of goodquality silage, because they predispose the occurrence of fermentations by the heterofermentative bacteria, if ensiled immediately after the cut, and without the inclusion of hygroscopic additive capable of retaining moisture and increasing the dry matter of the grass (McDonald, 1991). Ferrari Jr. and Lavezzo (2001) report that the inclusion of absorbent additives is essential for the dry matter content of the silage to increase. These authors stated that the elevated moisture content favored the development of bacteria of the genus Clostridium, producers of butyric acid, obtaining silage of bad quality.

Based on the dry matter content of $35 \%$ recommended by McDonald et al. (1991) as optimal for the process of lactic acid production, the level of $13.85 \%$ of inclusion of soybean hulls would be enough to reach this value.

Increasing linear behavior can be observed for the contents of crude protein (Table 3 ). This fact can be attributed to the likely reduction of proteolytic microorganisms, such as enterobacteria or clostridia, thus reducing the losses of protein nitrogen from the enriched silages. The inclusion

Table 3 - Chemical composition of Brachiaria decumbens grass silage with addition of soybean hulls levels, respective regression equations and coefficients of variation $(\mathrm{CV})$

\begin{tabular}{|c|c|c|c|c|c|c|c|c|}
\hline \multirow{2}{*}{ Variables } & \multicolumn{5}{|c|}{ Levels of soybean hulls (\%) } & \multirow{2}{*}{ Regression equation* } & \multirow{2}{*}{$\mathrm{CV} \%$} & \multirow{2}{*}{$\mathrm{R}^{2}$} \\
\hline & 0 & 10 & 20 & 30 & 40 & & & \\
\hline $\mathrm{DM}^{1}$ & 21.46 & 29.59 & 37.72 & 45.84 & 53.93 & $\mathrm{Y}=20.33+0.812 \mathrm{X}$ & 5.15 & 97.70 \\
\hline $\mathrm{CP}^{2}$ & 5.48 & 6.79 & 8.10 & 9.42 & 10.73 & $Y=4.166+0.131 X$ & 7.07 & 98.75 \\
\hline $\mathrm{EE}^{2}$ & 2.08 & 3.18 & 3.67 & 4.61 & 5.91 & $\mathrm{Y}=2.07+0.091 \mathrm{X}$ & 3.93 & 96.00 \\
\hline $\mathrm{NDFap}^{2}$ & 59.10 & 61.07 & 61.39 & 62.13 & 61.39 & $Y=56.18+0.339 X-0.004 X^{2}$ & 2.43 & 59.26 \\
\hline $\mathrm{ADF}^{2}$ & 29.52 & 33.26 & 36.95 & 40.64 & 44.33 & $Y=26.88+0.36 X$ & 7.17 & 96.32 \\
\hline HEM $^{2}$ & 30.48 & 27.36 & 24.24 & 21.12 & 18.00 & $Y=33.59-0.311 X$ & 8.94 & 98.86 \\
\hline $\mathrm{SC}^{2}$ & 6.77 & 7.94 & 8.22 & 8.31 & 8.53 & $Y=7.95$ & - & - \\
\hline $\mathrm{TDN}^{2}$ & 69.88 & 71.06 & 71.86 & 73.81 & 74.46 & $Y=70.00+0.11 X$ & 5.52 & 83.00 \\
\hline
\end{tabular}

\footnotetext{
${ }^{1}$ Percentage.
}

* Significant at $5 \%$ probability by the $\mathrm{t}$ test. 
of $21.63 \%$ soybean hulls in the ensilage of Brachiaria decumbens is sufficient to reach $7 \%$ crude protein in the silage, which is a value that, according to McDonald et al. (1991), guarantees the protein for maintenance of the rumen bacteria.

The control silage presented a low crude protein content and the highest value of $\mathrm{N}^{-\mathrm{NH}_{3}}$, indicating that there might have been losses of nutrients due to the production of effluent (Table 4), with possible leaking of soluble nitrogen compounds. Such behavior is in line with what McDonald (1981) reported, that in silages with $85 \%$ moisture, the losses by effluent leaching can exceed $9 \%$. This result reinforces the importance of the use of additives, increasing the reduction of moisture in grass silages.

The data on the CP of the silages were lower than those recorded by Monteiro et al. (2011), who observed $7.49 \%$ of $\mathrm{CP}$ in the silage with addition of soybean hulls at $14.98 \%$; such difference is a result of the better nutritional value of the elephant grass in relation to Brachiaria decumbens.

The inclusion of soybean hulls in the ensilage of the grass affected the ether extract content of the grass silage positively and linearly, promoting an increase of $0.09 \%$ for each $1 \%$ of soybean hulls added. This can be explained by the fact that the ether extract present in the soybean hulls is greater than that present in the forage.

It should be stressed that even at the highest level of inclusion $(40 \%)$ of soybean hulls, the ether extract value was 5.71 , which is below the critical level determined by the NRC (2001), which emphasizes that the total fat in the diet should not exceed 6 to $7 \%$ in the DM, as it may reduce the rumen fermentation, in the fiber digestibility and in the passage rate.

The contents of neutral detergent fiber corrected for ash and protein (NDFap) were quadratically affected by the additive $(\mathrm{P}<0.05)$, in such a way that the maximum value was estimated at $62.29 \%$ NDF for the level of $36.06 \%$ soybean hulls (Table 3 ).

Monteiro et al. (2011) observed quadratic behavior in the regression equation of the NDFap from silages with addition of soybean hulls in relation to the elephant grass silage. Ferrari Jr. and Lavezzo (2001), evaluating the NDFap content of the silage of elephant grass with inclusion of cassava meal at $0,2,4,8$ and $12 \%$, obtained silages with $72.91 ; 68.83 ; 68.51 ; 64.99$ and $60.37 \%$ NDFap, respectively.

The acid detergent fiber (ADF) content presented positive linear behavior $(\mathrm{P}<0.05)$, i.e., for each $1 \%$ soybean hulls included in the ensilage of grass, there was a decrease of $0.36 \%$ of ADF estimated by the equation. Comparing the $\mathrm{ADF}$ value estimated by the equation of the control silage (26.88\%) with the silage of highest level of inclusion of soybean hulls (41.64\%), there was an increase of 14.76 percentage points. This situation is explained by the greater content of ADF in the soybean hulls in relation to the ensiled grass (Table 1).

This behavior was contrary to those recorded by Garcia et al. (2003), who did not observe increase in the ADF content of grass silages with addition of $20 \%$ cottonseed meal and 20\% pelletized soybean hulls. However, Monteiro et al. (2011) reported that, in a study with elephant grass silages with addition of $0,5,10$ and $15 \%$ of soybean hulls, there was quadratic effect $(\mathrm{P}<0.05)$ of the levels of soybean on the ADF content of the forage, estimating a maximum value of $43.89 \%$ when soybean hulls was utilized at $13.65 \%$.

For hemicellulose (HEM), decreasing linear behavior $(\mathrm{P}<0.05)$ was observed with the use of additive. Each $1 \%$ soybean byproduct added to the ensilage of brachiaria grass promoted a decrease of $0.31 \%$ of hemicellulose (Table 2). This condition is a result of the estimation of the hemicellulose, which is based on the difference between the neutral and acid detergent fibers, in which as the additive was included, the hemicellulose value decreased proportionally.

Considering the fiber contents along with the other variables benefited by the additive in the present study, the intermediate level of $20 \%$ soybean hulls promoted values of $61.08 \%$ NDFap, $34.26 \%$ ADF and $27.36 \%$ HEM, so medium contents are acceptable for good-quality silage in diets for ruminants.

The inclusion of soybean hulls in the ensilage of the grass did not affect $(\mathrm{P}>0.05)$ the soluble carbohydrates content of the grass silage. This response emphasizes that the additive has the main function of increasing the dry

Table 4 - Losses through gases (LG), losses through effluents (LE), dry matter recovery (DMR) and the respective regression equations and coefficients of variation (CV) in the concentrations of soybean hulls in the silage of Brachiaria decumbens

\begin{tabular}{|c|c|c|c|c|c|c|c|c|}
\hline \multirow{2}{*}{ Variables } & \multicolumn{5}{|c|}{ Levels of soybean hulls (\%) } & \multirow{2}{*}{ Regression equation* } & \multirow{2}{*}{$\mathrm{CV} \%$} & \multirow{2}{*}{$\mathrm{R}^{2}$} \\
\hline & 0 & 10 & 20 & 30 & 40 & & & \\
\hline LG $(\% \mathrm{DM})$ & 8.55 & 7.36 & 6.16 & 4.97 & 3.77 & $Y=8.542-0.1195 X$ & 6.14 & 79.73 \\
\hline LE (\%DM) & 12.53 & 8.53 & 4.55 & 0.56 & 0.00 & $\mathrm{Y}=11.84-0.3303 \mathrm{X}$ & 7.26 & 65.29 \\
\hline DMR (\%DM) & 72.10 & 80.89 & 81.02 & 83.12 & 84.18 & $Y=74.498+0.2639 X$ & 9.69 & 62.49 \\
\hline
\end{tabular}

*Significant at $5 \%$ probability by the $t$ test. 
matter silage, but does not contribute to extra contribution of soluble carbohydrates in the fermentation (Table 3).

Increasing linear behavior $(\mathrm{P}<0.05)$ in the $\mathrm{TDN}$ content of the grass silage was also verified with increase in the levels of soybean hulls; each $1 \%$ of soybean hulls promoted an increase of $0.11 \%$ in the TDN content. Based on the levels of 0,20 and $40 \%$ estimated by the equation, the TDN value corresponded to $70.0,70.2$ and $74.4 \%$, respectively, which represented 2.2 more percentage points compared with the control silage, with that of $20 \%$ of inclusion of hulls, and 4.2 more percentage points in relation to the highest level of inclusion (40\%). In this aspect, in terms of efficiency, $20 \%$ was the best, because to raise 2.2 more percentage points, the cost:benefit ratio would have to be carefully analyzed, because it would be necessary to spend twice as many soybean hulls to reach the level of $40 \%$.

Behavior contrary to that observed in this study was verified by Monteiro et al. (2011) and Bernardino et al. (2005), who observed that the inclusion of up to $15 \%$ soybean hulls in the ensilage of elephant grass did not affect the TDN contents, estimating maximum value of 58.78 for $15 \%$ of inclusion. This can be attributed to the difference in the ether extract content found in the soybean hulls utilized in the present study to the level of this item in the soybean hulls utilized in the research of the abovementioned author, which is a situation that probably fostered the greater value of TDN in the present study.

The losses through gases and effluent were reduced linearly $(\mathrm{P}<0.05)$ as a function of the levels of soybean hulls (Table 4) added to the grass silage. A decrease of $0.11 \%$ was observed in the production of gas at every $1 \%$ of soybean hulls added, and of $0.33 \%$ in the production of effluents for every $1 \%$ of soybean hulls added to the grass forage, respectively.

According to Tavares et al. (2009), the high content of moisture favored the production of effluents, with consequent loss of nutrients and hence decrease in the nutritional value of the silages, unlike what was observed in silages with addition of $10,20,30$ and $40 \%$ of soybean hulls, in the present study. The decrease in the production of effluent in the enriched silages is due to their greater content of DM. McDonald et al. (1991) recommended 30\% of DM as the minimum value for the losses of effluent to be reduced, or the use of absorbent additives.

Considering the values estimated by the equation of losses through gases, the inclusion levels of 0,20,30 and $40 \%$ soybean hulls led to reduction of $8.54,6.15,4.96$ and $3.76 \%$, respectively; for the values of losses through effluents, this reduction was of $11.84,5.23,1.93$ and $0.00 \%$, respectively. Therefore, it can be precisely verified that the intermediate values of inclusion already promote significant improvement in the process of losses in these silages.

The benefits brought by small losses through gases and effluent reflected in the increasing linear behavior $(\mathrm{P}<0.05)$ of the recovery of DM from the enriched silages, in relation to the control silage. For each $1 \%$ of improved soybean hulls, there was an increase of 0.26 percentage units in the dry matter recovery (Table 4 ). The level of $20 \%$ soybean hulls, estimated by the equation, increased the DM recovery to $79.77 \%$, while in the control treatment this value was $74.49 \%$; at this intermediate level $(20 \%)$ there was a DM recovery of 5.28 percentage points. The lower values of losses and the greater DM recovery indicate that there was inhibition of heterofermentative bacteria, responsible for the elevation of the losses, probably as a consequence of the decrease in the $\mathrm{pH}$ of the silages.

\section{Conclusions}

Inclusion of soybean hulls reduces the losses through gases and effluents, increases the recovery of dry matter and improves the nutritional value and the fermentation pattern of silages of Brachiaria decumbens.

\section{References}

Bailey, R. W. 1967. Quantitative studies of ruminant digestion of ingested plant carbohydrates in the reticulo-rumen. New Zealand Journal of Agricultural Research 10:15-32.

Bernardino, F. S.; Garcia, R.; Rocha, F. C.; Souza, A. L. and Pereira, O. G. 2005. Produção e características do efluente e composição bromatológica da silagem de capim-elefante contendo diferentes níveis de casca de café. Revista Brasileira de Zootecnia $34: 2185-2191$

Ferrari Jr., E. and Lavezzo, W. 2001. Qualidade da silagem de capim-elefante (Pennisetum purpureum Schum) emurchecido ou acrescido de farelo de mandioca. Revista Brasileira Zootecnia 30:1424-1431.

Garcia, R.; Pereira, O. G.; Cecon, P. R. and Souza, A. L. 2003 Características do efluente e composição químico-bramatológica da silagem de capim-elefante. Revista Brasileira de Zootecnia 32:1851-1858

Kung, J. R. L. and Ranjit, N. K. 2001. The effect of Lactobacillus buchneri and other additives on the fermentation and aerobic stability of barley silage. Journal of Dairy Science 84:1149-1155.

Lima, P. G. C. 2009. Silagem de capim-elefante com adição de casca de soja. Dissertação (M.Sc.). Universidade Federal do Paraná, Maringá.

Licitra, G.; Hernandez, T. M. and van Soest, P. J. 1996. Standardization of procedures for nitrogen fractionation of ruminant feeds. Animal Feed Science and Technology 57:347-358.

McDonald, P. 1981. The biochemistry of silage. John Wiley \& Sons, Chichester.

McDonald, P.; Henderson, A. R. and Heron, S. J. E. 1991. The biochemistry of silage. 2nd ed. Chalcombe Publications, Mallow. 
McGechan, M. B. 1989. A review of losses arising during conservation of grass forage:Storage losses. Journal Agricultural Engineering Research 45:1-30.

Mertens, D. R. 2002. Gravimetric determination of amylase treated neutral detergent fiber in feeds with refluxing in beaker or crucibles: collaborative study. Journal of OAC International $85: 1217-1240$

Monteiro, I. J. G.; Abreu, J. G.; Cabral, L. S.; Ribeiro, M. D. and Reis, R. H. P. 2011. Silagem de capim-elefante aditivada com produtos alternativos. Acta Scientiarum 33:347-352.

NRC - National Research Council. 2001. Nutrient requirement of dairy cattle. 7th ed. National Academy, Washington, DC.

Pires, A. J. V.; Carvalho, G. J. P.; Garcia, R.; Carvalho Junior, J. N.; Ribeiro, L. S. O. and Chagas, D. M. T. 2009. Capim elefante ensilado com casca de café, farelo de cacau ou farelo de mandioca. Revista Brasileira de Zootecnia 38:34-39.

Playne, M. J. and McDonald, P. 1966. The buffering constituents of herbage and of silage. Journal of the Science of Food and Agricultural 17:264-268.

Ribeiro, R. D. X.; Oliveira, R. L.; Bagaldo, A. R.; Faria, E. F. S.; Garcez Neto, A. F.; Silva, T. M.; Borja, M. S. and Cardoso Neto, B. M. 2008. Capim tanzânia ensilado com níveis de farelo de trigo. Revista Brasileira de Saúde e Produção Animal 9:631-640.
Silva, D. J. and Queiroz, A. C. 2002. Análise de alimentos, métodos químicos e biológicos. 3.ed. UFV, Viçosa, MG, Brasil.

Tavares, V. B.; Pinto, J. C.; Evangelista, A. R.; Figueiredo, H. C. P.; Ávila, C. L. S. and Lima, R. F. 2009. Efeitos da compactação, da inclusão de aditivo absorvente e do emurchecimento na composição bromatológica de silagens de capim-tanzânia. Revista Brasileira de Zootecnia 38:40-49.

Tosi, H. 1973. Ensilagem de gramíneas tropicais sob diferentes tratamentos. Tese (D.Sc.). Faculdade de Ciências Médicas e Biológicas de Botucatu, Botucatu.

Van Soest, P. J. 1994. Nutritional ecology of the ruminant. 2nd ed. Cornell University Press, Ithaca.

Zanine, A. M.; Santos, E. M.; Ferreira, D. J.; Dórea, J. R. R.; Dantas, P. A. S.; Silva, T. C. and Pereira, O. G. 2006a. Efeito do farelo de trigo sobre as perdas, recuperação da matéria seca e composição bromatológica de silagem de capim-mombaça. Brazilian Journal of Veterinary Research and Animal Science 54:1-10.

Zanine, A. M.; Santos, E. D.; Ferreira, D. J.; Oliveira, J. S.; Almeida, J. C. C. and Pereira, O. G. 2006b. Avaliação da silagem de capim-elefante com adição de farelo de trigo. Arquivos de Zootecnia 55:75-84.

Zanine, A. M.; Santos, E. M.; Dorea, J. R. R.; Dantas, P. A. S.; Silva, T. C. and Pereira, O. G. 2010. Evolution of elephant-grass silage with the addition of cassava scrapings. Revista Brasileira de Zootecnia 12:2611-2616. 